\title{
The effects of fresh embryo transfers and elective frozen/ thawed embryo transfers on pregancy outcomes in poor ovarian responders as defined by the Bologna criteria
}

\author{
Bologna kriterlerine uyan zayif cevapli kadinlarda taze ve \\ elektif dondurulmuş/çözülmüş embriyo transferlerinin gebelik \\ sonuçlarına etkisi
}

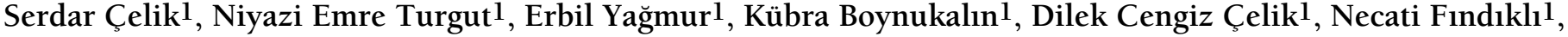 \\ Sevim Purisa ${ }^{2}$, Mustafa Bahçecil

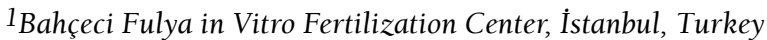 \\ 2İstanbul University Faculty of Medicine, Department of Biostatistics and Medical Informatics, İstanbul, Turkey
}

\begin{abstract}
Objective: To compare the effects of fresh embryo transfers (ET) and elective frozen/thawed embryo transfers (eFET) on implantation, clinical pregnancy, and live birth rates in poor ovarian responders, as defined by the Bologna criteria.

Materials and Methods: All electronic databases of embryo transfers between January 2011 and January 2014 were retrospectively reviewed. Two hundred fifty-nine of all the fresh ET and 96 of all eFET were included into the study. An antagonist protocol with letrozole was used for the controlled ovarian hyperstimulation $(\mathrm{COH})$ in all participants.

Results: The mean age was 36.9 years (range, 21-43 years) in the fresh ET arm and 37.2 years (range, 21-43 years) in the eFET arm ( $\mathrm{p}=0.45$ ). The clinical pregnancy rate was 35\% (90/259) versus 29\% (28/96); the abortion rate was 27\% (20/75) versus 36\% (9/25); and the live birth rate was 21\% (55/259) versus $17 \%(16 / 99)$. There were no significant differences between groups and p values were $0.32,0.52$, and 0.42 , respectively. The mean E2 level was 389 (range, $50-2055 \mathrm{pg} / \mathrm{mL}$ ) in the fresh ET group (on hCG day) and $418 \mathrm{pg} / \mathrm{mL}$ (range, $121-3073 \mathrm{pg} / \mathrm{mL}$ ) in the eFET group (on day 14 of cycle) (p=0.122). No differences were found between the two groups with respect to the total number of retrieved oocytes ( $\mathrm{p}=0.55)$ and number of metaphase II (MII) oocytes $(\mathrm{p}=0.81)$. The number of embryo transfers was statistically different $(\mathrm{p}=0.005)$. The effects of age, total number of retrieved oocytes, number of MII oocytes, type of treatment, number of ET, and the day of ET and E2 level to live birth outcomes were investigated using binary logistic regresion analyses, and no stastical effect was determined by any of the parameters. $P$ values were $p=0.50,0.66,0.45,0.30,0.30,0.08$, and 0.90 , respectively.

Conclusion: E2 levels tend to be lower in poor responders, thus the receptivity of the endometrium may be damaged less than normal, which may explain why pregnancy results are the same between eFET and ET groups.

Keywords: Poor responder, frozen embryo transfer, endometrial receptivity

$\ddot{O} z$

Amaç: Bologna kriterlerine uyan zayıf cevaplı hastalarda taze ve elektif dondurulmuş/çözülmüş embriyo transferlerinin (ET) implantasyon, klinik gebelik ve doğum oranlarına etkisini karşılaştırılmaktır.

Gereç ve Yöntem: Ocak 2011- Ocak 2014 tarihleri arasında tedaviye alınan tüm hastaların ET işlemleri elektronik kayıtları kullanılarak tarandı. İki yüz elli dokuz taze ve 96 dondurulmuş/çözülmüş ET yapılan kadın çalışmaya alındı. Kontrollü ovarian hiperstimulasyonu (KOH) için letrozol/antagonist protokolü yapılan hastalar çalışmaya alındı.

Bulgular: Taze ET kolunda yaş 36,9 (min 21-max 43) ve dondurulmuş/çözülmüş ET kolunda ise 37,2 (min 21-max 43) olarak saptandı (p=0,45). Klinik gebelik oranı \%35'e (90/259) karşın \%29 (28/96), abortus oranı \%27'e (20/75) karşın \%36 (9/25), canlı doğum oranı \%21'e (55/259) karşın \%17 (16/99) olarak saptandı. Gruplar arasında istatistiki fark saptanmadı sırası ile p değerleri, 0,32, 0,52, 0,42. Ortalama E2 değeri taze ET (Hcg günü) kolunda 389 pg/ ml (min 50-max 2055) iken dondurulmuş/çözülmüş ET (siklusun 14. günü) kolunda 418 pg/ml (min 121-max 3073) olarak saptandı (p=0,122). Gruplar arasında toplam oosit sayısı $(\mathrm{p}=0,55)$, metafaz II oosit sayısı $(\mathrm{p}=0,81)$ benzer saptandi. Transfer edilen embriyo sayısı farklı bulundu ( $\mathrm{p}=0,005)$. Binary lojistik regresyon analizi yapılarak yaş, elde edilen toplam oosit sayısı, metafaz II oosit sayısı, tedavi şekli, ET sayısı ET günü ve E2 değerlerinin canlı doğum sonuçlarına etkisi araştırıldı. Hiçbir parametrenin canlı doğuma etki etmediği saptandı. Sırası ile p değerleri p=0,50, 0,66, 0,45, 0,30, 0,30, 0,08, 0,90.
\end{abstract}


Sonuç: Zayıf cevaplı hastalar, genç hastalara göre KOH sırasında östrojen seviyelerinin çok fazla yükselmemesi nedeni ile endometrial reseptivite daha az zarar görür ve bundan dolayı gebelik sonuçları taze ve dondurulmuş/çözülmüş ET gruplarında benzerdir.

Anahtar Kelimeler: Zayıf overyan yanıt, dondurulmuş embriyo transferi, endometrial reseptivite

\section{Introduction}

The success rates among infertility treatments are steadily increasing with the new technological developments in the multiple oocyte collecting process through controlled ovarian hyperstimulation $(\mathrm{COH})$ and cryopreservation methods. However, pregnancy rates in patients who are so-called poor responders are still low $(1,3)$.

For a successful implantation, there has to be a good quality embryo as well as a normal receptive endometrium. In natural cycles, endometrial receptivity arises 6 to 10 days after ovulation and this period is called the "implantation window" (4). The quality of receptivity in this time frame plays an important role in in vitro fertilisation/intracytoplasmic sperm injection (IVF/ICSI) failures(5). In $\mathrm{COH}$ cycles, endometrial receptivity is negatively effected because of the supraphysiologic hormonal environment ${ }^{(6-9)}$.

The definition of poor ovarian response varies in the literature. Some of the criteria used to define poor resonders are serum E2 levels less than $500 \mathrm{pg} / \mathrm{mL}$;(10) antral follicle count (AFC) less than 3;(11) retrieval of less than 3 oocytes in a previous situmulation protocol;(12) and the level of day 3 follicle stimulating hormone (FSH) $>12 \mathrm{mIU} / \mathrm{mL}^{(13)}$. Recently, Ferraretti et al.(14) published their detailed poor-responder definition.

The aim of this study was to compare the effects of elective frozen/thawed (eFET) and fresh embryo transfers (ET) on implantation rates, clinical pregnancy, and live birth outcomes in poor ovarian responders, as defined by the Bologna criteria.

\section{Materials and Methods}

This study was carried out in Bahçeci Fulya IVF Center, İstanbul. The records were retrospectively reviewed and as such there was no need for ethical committee approval.

All electronic records of embryo transfers between January 2011 and January 2014 were analyzed. Overall, 14601 patients were reviewed. Two hundred fifty-nine patients comprised the fresh ET arm and 96 were included the eFET arm of the study. To ensure homogeneity between groups and show the effectiveness of embryo transfers, exclusion criteria were carefully generated as follows;

i) $\mathrm{AFC} \geq 6-8$

ii) $4 \geq 0$ ocytes retrieved in previous $\mathrm{COH}$

iii) Aged over 43 years on the day of embryo transfer

iv) Dehydroepiandrosterone (DHEA) or growth hormone (GH) therapy before $\mathrm{COH}$

v) The $\mathrm{COH}$ protocols of those who did not use the letrozole/ antagonist regime

vi) History of difficult embryo transfer and use of a hard catheter (Wallace Sure-Pro, Two-Stage set, UK) vii) Progesteron level higher than $1.5 \mathrm{ng} / \mathrm{mL}$ on the human chorionic gonadotropin (hCG) day for fresh EET cycles, and on day 14 of treatment for the eFET cycles.

All patients who met the definition of Ferraretti et al.(14) as poor responders were included in the study.

Second embryo transfers with remaining frozen/thawed embryos in the eFET arm were excluded from present study. Frozen/thawed blastocysts were transfered without undergoing preimplantation genetic tests for aneuploidy screening or other anomalies. All patients used their own oocytes because donor oocytes are strictly forbidden in Turkey.

To evaluate the endometrial receptivity, E2 levels were measured on day 14 of the cycle for the eFET arm and on hCG day for the fresh ET arm.

\section{Stimulation protocol}

Letrozole (Femara; Novartis, İstanbul, Turkey) $2.5 \mathrm{mg}$ was started twice daily on day 2 of the current cycle and used for 5 days. Human menopausal gonadotropin (hMG) 300-450 IU (Merional; IBSA Institut Biochimique SA Lamone, Switzerland) was initiated on day 7 of the cycle and ovarian response was evaluated using transvaginal sonography and serum E2 levels. The gonadotropin-releasing hormone antagonist (Cetrotide; Serono, Turkey) was administered when the leading follicle reached 11-13 $\mathrm{mm}$ and used until to final triggering. Two ampoules of recombinant hCG (Ovitrelle; Serono, Turkey) was administered as soon as the leading follicle reached a mean diameter of $18 \mathrm{~mm}$. We believe we can pick up more mature oocytes using $500 \mu \mathrm{g}$ recombinant hCG in patients who are poor responders(15). The oocyte pick-up procedure was performed 34-36 hours after recombinant hCG injection using transvaginal ultrasound-guided needle aspiration under general anesthesia.

\section{Luteal support}

After the oocyte retrieval, vaginal progesteron gel (Crinone 8\%, MerckSerono, Bedfordshire, UK) $90 \mathrm{mg}$ was used twice a day(16) until the pregnancy test. For positive test results, luteal phase support was maintained up to the $10^{\text {th }}$ week of pregnancy.

\section{Endometrial preparation}

Transdermal estradiol hemihydrate patches (Climara Forte, Bayer, İstanbul, Turkey) were started on either of day 3 of the following cycle or as $100 \mathrm{mcg} /$ day for the first 4 days of the next cycle, $200 \mathrm{mcg} /$ day for the following 4 days, and $300 \mathrm{mcg} /$ day for the last 4 days. Serum progesterone level and endometrial thickness were then measured. Treatment was continued if progesterone level $<1.5 \mathrm{ng} / \mathrm{mL}$, endometrial thickness $>8$ $\mathrm{mm}$ and had a triple-line appearance. Vaginal progesteron gel (Crinone 8\%, MerckSerono, Bedfordshire, UK) $90 \mathrm{mg}$ was 
prescribed twice a day. A transdermal estradiol hemihydrate patch $100 \mathrm{mcg} /$ day and vaginal progesterone gel at the same dosage were maintained until the pregnancy test. For positive test results, patients used vaginal progesterone up to the $10^{\text {th }}$ week of pregnancy.

\section{Protocol for vitrification and embryo-thawing}

We prepared our own solutions for embryo vitrification and thawing procedures. Day 2-3 embryos and day 5-6 embryos were put in an equilibration solution at room temperature for 6-8 minutes and 10-12 minutes, respectively. They were then kept in the vitrification solution for 40 seconds and directly submerged into liquid nitrogen after loading into the cryovial. For thawing, the cryovial was taken out of the liquid nitrogen, kept in the first thawing solution at $37^{\circ} \mathrm{C}$ for 1 minute, in the second thawing solution at room temperature for 3 minutes, and then transferred into the culture solution to be put into the incubator afterwards.

\section{Pregnancy definitions}

Serum hCG levels were evaluated 12 days after embryo transfer. Values $>5 \mathrm{mIU} / \mathrm{mL}$ were accepted as a positive result.

Clinical pregnancy was defined as an intrauterine sac envisioned using transvaginal sonography at 7 weeks of gestation.

Live birth was defined as birth of one or more infants including a gestational age of $\geq 20$ weeks $(17)$.

Abortion was defined as an unintentional expulsion of an embryo or fetus before the $20^{\text {th }}$ week of gestation.

\section{Statistical analysis}

Pregnancy rates per patient and per ET were calculated by dividing intrauterine gestational sac number by all cohorts and the number of transferred embryos.

Clinical pregnancy rates per patient and per ET were calculated by dividing the number of all women with intrauterine sacs by all cohort and the number of transferred embryos.

Live birth rates per patient and per transferred embryo were calculated by dividing the total number of births at a gestational age of $\geq 20$ weeks by all cohort and transferred embryos.
Abortion rates were obtained by dividing the number of pregnancy losses by the number of clinical pregnancies.

Dichorionic pregnancies were accepted as two gestational sacs, but monochorionic pregnancies as one.

Distribution characteristics of variables were assessed with histograms, Kolmogorov-Smirnov and One-Sample test. Data is presented as median, minimum, maximum, frequency and percentage. Quantitative variables that seemed to affect live birth outcomes were analyzed using the Mann-Whitney U test. Categorical variables were compared using the Chi-Square test. $\mathrm{P}<.05$ was considered to be statistically significant. Logistic regresion analysis was used to investigate factors that affected live birth outcomes. Statistical calculations were performed using the Statistical Package for the Social Sciences (SPSS), version 21.0.

\section{Results}

Three hundred fifty-five women were enrolled into the study. Groups were generated as the fresh ET arm, which included 259 patients, and the eFET transfer arm, comprised by 96 patients.

Age, metaphase II oocyte (MII) distribution, total number of retrieved oocytes, and pregnancy outcomes were similar in both treatment arms ( $\mathrm{p}=0.45,0.51,0.55,0.66$, respectively). The mean serum E2 level measured on hCG trigger day in the fresh ET arm was $389 \mathrm{pg} / \mathrm{mL}$ (range, 50-2055 pg/mL) and on day 14 of the cycle in the eFET arm it was $418 \mathrm{pg} / \mathrm{mL}$ (range, 121-3073 $\mathrm{pg} / \mathrm{mL}$ ). There was no significant difference between groups regarding serum E2 levels $(p=0.12)$. In addition, the mean number of transferred embryos was 1 (range, 1-2) in the fresh ET arm and 2 (range, 1-2) in the eFET arm; this difference was statistically different between the groups $(\mathrm{p}=0.005)$ (Table 1 ). In the fresh ET arm, 164 (63\%) out of 259 transfers were single embryo transfers (SET) and in 51 (53\%) out of 96 transfers in the eFET arm were double embryo transfers (DET). There was no significant difference with respect to implantation rates between the groups $(\mathrm{p}=0.66)$.

Table 1. Demographic parameters are displayed. Age, MII oocyte distrubition, total retrieved oocyte number and pregnancy outcomes were similar in both treatment arms but the number of transferred embryos were significantly different

\begin{tabular}{|c|c|c|c|}
\hline & eFET & Fresh ET & $\mathrm{p}$ \\
\hline Age (years) & 37.2 (range, 21-43) & 36,9 (range, 21-43) & 0.45 \\
\hline \multicolumn{4}{|l|}{ Pregnancy outcome } \\
\hline Positive & 31 & 90 & \multirow[t]{2}{*}{0.66} \\
\hline Negative & 65 & 169 & \\
\hline Estradiol level (pg/mL) & 418 (range, 121-3073) & 389 (range, 50-2055) & 0.12 \\
\hline MII & 2 (range, $0-3$ ) & 2 (range, $0-3$ ) & 0.81 \\
\hline Number of embryo transfer & 2 (range, $1-2$ ) & 1 (range, $1-3$ ) & $0.005^{*}$ \\
\hline Total number of retrieved oocyte & 2 (range, $1-3$ ) & 2 (range, 1-3) & 0.55 \\
\hline
\end{tabular}


Positive pregnancy test results were obtained in 90/259 (35\%) in the fresh ET arm, and in 31/96 (32.3\%) in the eFET arm $(\mathrm{p}=0.66)$. The number of single gestational sacs was $70 / 259$ (27\%) and 22/96 (22\%), and double sacs was 10/259 (3.9\%) and $3 / 96(3.1 \%)$, respectively. The clinical pregnancy rates in both groups were 35\% (90/259) versus 29\% (28/96) and no stastical difference was determined $(\mathrm{p}=0.32)$. The number of missed abortions was 20/75 (27\%) with fresh ET and 9/25 (36\%) with eFET $(\mathrm{p}=0.52)$, and the number of biochemical pregnancies was $9 / 259$ (3.5\%) and 5/96 (9.4\%), respectively. Two ectopic pregnancies were diagnosed in the fresh ET group. The number of live births was 55/259 (21\%) in the fresh ET group and 16/96 (17\%) in the eFET group; no stastical difference was noted $(\mathrm{p}=0.34)$.

There was no significant difference related to pregnancy, clinical pregnancy, and live birth outcomes per number of embryo transfers ( $\mathrm{p}=0.30,0.13$, and 0.17 , respectively) (Table 2).

The distrubition of the day of embryo transfers between groups were different. The number of clevage stage embryo transfers in the fresh ET arm was higher than in the eFET arm (250/259 (96.5\%); 85/96 (85.4\%)), and the number of blastocyst transfers was higher in the eFET arm (14/96 (15\%); 9/259 $(4 \%))(\mathrm{p}=0<001)$.

The effects of total number of retrieved oocytes, number of MII oocytes, number of transferred embryo, day of ET, type of treatment, and age to live birth outcomes were evaluated seperately. Only age was found as an affecting variable. $P$ values were $0.65,0.30,0.62,0.16,0.42,0.001$, respectively (Table 3). In addition, we conducted subgroup analyses and found a positive effect of blastocyst transfer on live birth rates. The live birth rate was 32\% (13/41) after blastocyst transfer and 19\% (58/314) after cleavage stage embryo transfer $(\mathrm{p}=0.036)$.

The effects of age, total number of retrieved oocytes, number of MII oocytes, type of treatment, number of ET, the day of ET, and serum E2 to live birth outcomes were investigated using binary logistic regresion analyses. The Nagelkerke R2 value was 0.75 , Hosmer-Lemeshow goodness of fit test was $p=0.99$, and the estimation percentage of model was $89.5 \%$. None of the variables were found as a risk factor in live birth outcomes ( $\mathrm{p}=0.50,0.66,0.45,0.30,0.30,0.08,0.90$, respectively). Although age was different in univariate analyses, no difference was found in multivariate analyses.

\section{Discussion}

In this study we found no significant differences regarding clinical pregnancy, abortion, and live birth rates between the eFET and fresh ET groups.

Prostaglandin synthesis is diminished in the early pregnancy period. It has been reported that increased levels of prostaglandins may be a cause of early pregnancy loss $(18,19)$. Prostaglandin levels tend to be higher after oocyte retrieval and this may be the reason for increased numbers of early pregnancy losses in fresh embryo transfer cycles, and also for early ovarian hyperstimulation syndrome (OHSS)(20,21). For this reason, it has been claimed that eFET cycles are similar to natural cycles. However, younger age groups and patients who were normoresponders comprised the cohorts in the aforementioned studies. In the present study, the mean age of the eFET arm was 37.2 years (range, 21-43 years) and 36.9 years (range, 21-43 years) in the fresh ET arm, hence higher abortion rates were observed at $27 \%$ and $36 \%$ respectively, which were consistent with the literature(22). Oocyte-induced factors have been suggested for these higher and similar abortion rates. Beyond this factor, uterine microenvironments may resemble each other owing to similar levels of estrogen.

It has been argued that the supraphysiologic hormonal microenvironment in fresh ETcycles may negatively affect the implantation process $(20,23)$. $\mathrm{COH}$ procedures may change the gene expression profile of endometrium. There may be alterations in E2 and progesteron receptors in stimulated cycles; therefore, endometrium maturation may be negatively affected with respect to normal endometrium(24).

Supraphysiologic serum levels of E2 (>2500 pg/mL) may hamper endometrial maturation and implantation, hence

Table 2. Pregnancy outcomes are displayed. In both treatment arms there was no stastical difference regarding the number of pregnancies, clinical pregnancies, abortion, live births per number of patients, or the number of transferred embryos

\begin{tabular}{|c|c|c|c|c|}
\hline & eFET & Fresh ET & Total count & $\mathbf{p}$ \\
\hline Pregnancy outcome per patient & $31 / 96(32 \%)$ & $90 / 256(35 \%)$ & 355 & 0.66 \\
\hline Clinical pregnancy outcome per patient & $28 / 96(29 \%)$ & $90 / 256(35 \%)$ & 355 & 0.32 \\
\hline Live birth outcome per patient & $16 / 96(17 \%)$ & $55 / 256(2 \%)$ & 355 & 0.34 \\
\hline Pregnancy outcome per transferred embryo & $31 / 147(21 \%)$ & $90 / 354(25 \%)$ & 501 & 0.30 \\
\hline Clinical pregnancy outcome per transferred embryo & $28 / 147(19 \%)$ & $90 / 354(25 \%)$ & 501 & 0.13 \\
\hline Live birth outcome per transferred embryo & $16 / 147(10 \%)$ & $55 / 354(16 \%)$ & 501 & 0.17 \\
\hline Abortion & $9 / 25(36 \%)$ & $20 / 75(27 \%)$ & 100 & 0.52 \\
\hline Ectopic pregnancy & 0 & $2(0.11 \%)$ & 355 & 0.54 \\
\hline
\end{tabular}


pregnancy rates in these cycles are lower. Reducing serum levels of E2 in the preimplantation period may improve pregnancy outcomes(25-27). However, a systematic review and metaanalyses comparing fresh ET and eFET reported higher clinical and pregnancy rates in the eFET group among patients who were normoresponders; (28) no consensus exists for patients who are poor responders.

In the present study, we noted similar serum E2 levels in both arms. During endometrial preparation, the mean serum estradiol level on day 14 was $418 \mathrm{pg} / \mathrm{mL}$ (range, $121-3073 \mathrm{pg} /$ $\mathrm{mL}$ ) in the eFET arm, and $389 \mathrm{pg} / \mathrm{mL}$ (range, $50-2055 \mathrm{pg} / \mathrm{mL}$ ) in the fresh ET arm on the day of hCG trigger $(p=0.12)$. These findings displays a similarity between groups with respect to endometrial receptivity and pregnancy outcomes.

Letrozole, a nonsteroidal reversible aromatase inhibitor, is used in in vitro fertilization cycles among patients who are poor responders. It is thought to inhibit peripheral conversion of androgens to estrogen by blocking aromatization and decreases negative estrogen feed back to the pitutary gland(29). Sequential use of letrozole and gonadotropins has been reported as a better method for follicular growth in poor responders(30). Furthermore, decreased estradiol levels have been documented in letrozole cycles compared with long protocols(31). Several later studies supported these findings(29,32-34). Letrozole use in the course of the hyperstimulation period may cause more physiologic endometrial receptivity. In the present study, only patients who used used letrozol/antagonist treatment were included in the fresh ET arm. In this way, we aimed to prevent estradiol increments and provide more physiologic endometrial receptivity as a consequnece. In addition, the diminished antral follicle count may be a reason for decreased estradiol levels in $\mathrm{COH}$ procedures among patients who are poor responders $(10)$. Progesteron is one of the other hormones that disrupts endometrial receptivity(28). Levels higher than $1.5 \mathrm{ng} / \mathrm{mL}$ on the day of the hCG trigger negatively affects pregnancy outcomes(35). In our study, progesterone levels above $1.5 \mathrm{ng} / \mathrm{mL}$ on the day of hCG trigger were exclusion criteria for the fresh ET arm and on day 14 for the eFET arm. Thus, the potential negative impacts of progesterone on endometrial receptivity was prevented.

Endometrial receptivity may be hampered much less in poor responders because of lower serum E2 levels in $\mathrm{COH}$ cycles. In this manner, pregnancy outcomes between groups would be similar. We believe that the decreased pregnancy rates among poor responders are due to oocyte factors.

There is no consensus regarding the ET day in poor responders(36-39). The disparities in embryo transfer days may not be controlled between the eFET and fresh ET groups due to the retrospective design of our study. Among all patients, 23 (7\%) out of 355 were blastocyst transfers and the remainder (332/355; 93\%) consisted of cleavage stage embryo transfers. The blastocyst

Table 3. Factors effecting live birth outcomes are displayed. Younger age has increased live birth rate. Total number of retrieved oocyte, number of MII oocytes, type of treatment, number of ET, the day of ET are not effecting live birth rates

\begin{tabular}{|c|c|c|c|c|}
\hline & & Negative & Live birth & $\mathrm{p}$ \\
\hline \multirow{3}{*}{ TRO } & 1 & $47(84 \%)$ & $9(16 \%)$ & \multirow{3}{*}{0.65} \\
\hline & 2 & $107(78 \%)$ & $30(22 \%)$ & \\
\hline & 3 & $130(80 \%)$ & $32(20 \%)$ & \\
\hline \multirow{4}{*}{ MII } & 0 & $4(100 \%)$ & 0 & \multirow{4}{*}{0.31} \\
\hline & 1 & $90(85 \%)$ & $16(15 \%)$ & \\
\hline & 2 & $125(78 \%)$ & $36(22 \%)$ & \\
\hline & 3 & $65(77 \%)$ & $19(23)$ & \\
\hline \multirow{2}{*}{ Number of transferred embryos } & 1 & 169 (81\%) & 40 (19\%) & \multirow{2}{*}{0.62} \\
\hline & 2 & $115(79 \%)$ & $31(21 \%)$ & \\
\hline \multirow{4}{*}{ ET days } & 2 & $175(83 \%)$ & $36(17 \%)$ & \multirow{4}{*}{0.16} \\
\hline & 3 & $81(79 \%)$ & $22(22 \%)$ & \\
\hline & 4 & $13(72 \%)$ & $5(28 \%)$ & \\
\hline & 5 & $15(65 \%)$ & $8(35 \%)$ & \\
\hline \multirow{2}{*}{ Type of treatment } & eFET & $80(83 \%)$ & $16(17 \%)$ & \multirow{2}{*}{0.42} \\
\hline & fresh ET & $204(79 \%)$ & $55(21 \%)$ & \\
\hline \multirow{2}{*}{$\begin{array}{l}\text { Age group } \\
\text { (years) }\end{array}$} & $<35$ & 68 (68\%) & $32(32 \%)$ & \multirow{2}{*}{$0.001^{*}$} \\
\hline & $\geq 35$ & $216(85 \%)$ & $71(15 \%)$ & \\
\hline
\end{tabular}

eFET: Elective frozen/thawed embryo transfer, Fresh ET: Fresh embryo transfer, ET: Embryo transfer, MII: Metaphase II oocyte, TRO: Total number of retrieved oocyte, ${ }^{*} \mathrm{p}<0.05$ is accepted as significant 
transfer rate was higher in the eFET arm, and the cleavage stage embryo transfer rate was higher in the fresh ET arm $(\mathrm{p}<0.001)$. There was no detrimental effect observed regarding the day of embryo transfer on live birth rates, even though the distrubition of transfer days were different in both arms ( $\mathrm{p}=0.08)$.

Our study was of a retrospective design and did not eliminate confounding factors such as smoking, Body mass index (BMI), duration of infertility, and underlying sistemic diseases. Further large randomized controlled studies are needed because of these limitations.

In conclusion, we found similar pregnancy results among patients who were poor responders in both treatment arms. We believe that similar serum E2 levels and as a result, similar endometrial receptivity patterns might be the main reason for this finding.

Ethics Committee Approval: The records were retrospectively reviewed and as such there was no need for ethical committee approval. However, the Institutional Review Board of Bahceci IVF Center approved the study protocol, Informed Consent: Consent form was filled out by all participants, Concept: Serdar Çelik, Dilek Cengiz Çelik, Mustafa Bahçeci, Design: Serdar Çelik, Dilek Cengiz Çelik, Kübra Boynukalın, Necati Fındıklı, Data Collection or Processing: Serdar Çelik, Erbil Yağmur, Niyazi Emre Turgut, Analysis or Interpretation: Serdar Çelik, Niyazi Emre Turgut, Kübra Boynukalın, Dilek Cengiz Çelik, Sevim Purisa, Mustafa Bahçeci, Literature Search: Serdar Çelik, Dilek Cengiz Çelik, Erbil Yağmur, Writing: Serdar Çelik, Dilek Cengiz Çelik, Niyazi Emre Turgut, Peer-review: External and Internal peer-reviewed, Conflict of Interest: No conflict of interest was declared by the authors, Financial Disclosure: The authors declared that this study has received no financial support.

\section{References}

1. Vlahos N, Papalouka M, Triantafyllidou O, Vlachos A, Vakas P, Grimbizis $G$, et al. Dehydroepiandrosterone administration before IVF in poor responders: a prospective cohort study. Reprod Biomed Online 2015;30:191-6.

2. Oudendijk J, Yarde F, Eijkemans M, Broekmans F, Broer S. The poor responder in IVF: is the prognosis always poor? a systematic review. Human Reprod Update 2011;18:1-11.

3. Zhen XM, Qiao J, Li R, Wang LN, Liu P. The clinical analysis of poor ovarian response in in-vitro-fertilization embryo-transfer among Chinese couples. J Assist Reprod Genet 2008;25:17-22.

4. Navot D, Bergh P. Preparation of the human endometrium for implantation. Ann N Y Acad Sci 1991;622:212-9.

5. Evans J, Hannan NJ, Edgell TA, Vollenhoven BJ, Lutjen PJ, Osianlis T, et al. Fresh versus frozen embryo transfer: backing clinical decisions with scientific and clinical evidence. Human Reprod Update 2014;20:808-21.

6. Bourgain C, Devroey P. The endometrium in stimulated cycles for IVF. Hum Reprod Update 2003;9:515-22.

7. Shapiro BS, Daneshmand ST, Garner FC, Aguirre M, Hudson C, Thomas S. Evidence of impaired endometrial receptivity after ovarian stimulation for in vitro fertilization: a prospective randomized trial comparing fresh and frozen-thawed embryo transfers in high responders. Fertility and Sterility 2011;96:516-8.
8. Thomas K, Thomson AJ, Sephton V, Cowan C, Wood S, Vince G, et al. The effect of gonadotrophic stimulation on integrin expression in the endometrium. Human Reprod 2002;17:63-8.

9. Xiao Z, Zhou X, Xu W, Yang J, Xie Q. Natural cycle is superior to hormone replacement therapy cycle for vitrificated-preserved frozenthawed embryo transfer. Syst Biol Reprod Med 2012;58:107-12.

10. Demirol A, Gurgan T. Comparison of microdose flare-up and antagonist multiple-dose protocols for poor-responder patients: a randomized study. Fertil Steril 2009;92:481-5.

11. Frattarelli JL, Hill MJ, McWilliams GD, Miller KA, Bergh PA, Scott RT Jr. A luteal estradiol protocol for expected poor-responders improves embryo number and quality. Fertil Steril 2008;89:1118-22.

12. Tehraninejad ES, Fazel A, Samiei A, Rashidi B, Kiani K. Flexible, multi-dose GnRH antagonist versus long GnRH agonist protocol in poor responders: a randomized controlled trial. Int J Fertil Steril 2009;2:165-8.

13. Massin N, Cedrin-Durnerin I, Coussieu C, Galey-Fontaine J, Wolf J, Hugues JN. Effects of transdermal testosterone application on the ovarian response to FSH in poor responders undergoing assisted reproduction technique-a prospective, randomized, double-blind study. Human Reprod 2006;21:1204-11.

14. Ferraretti A, La Marca A, Fauser BC, Tarlatzis B, Nargund G, Gianaroli L. ESHRE consensus on the definition of 'poor response'to ovarian stimulation for in vitro fertilization: the Bologna criteria. Hum Reprod 2011;26:1616-24.

15. Park KE, Jee BC, Suh CS, Kim KC, Lee WD, Kim SH. Optimal recombinant hCG dose for final oocyte maturation triggering in poor responders. Fertil Steril 2012;98(Suppl):157.

16. Bulent Urman SC, Kayhan Yakin, Ebru Alper, Basak Balaban, Baris Ata: vaginal progesterone gel for luteal support after cleavage stage embryo transfer, once or twice a day?journal of reproductive medicine 2014, in press(optimal dose of vaginal progesterone).

17. Zegers-Hochschild F, Adamson GD, de Mouzon J, Ishihara O, Mansour $\mathrm{R}$, Nygren $\mathrm{K}$, et al. The international committee for monitoring assisted reproductive technology (ICMART) and the world health organization (WHO) revised glossary on ART terminology, 2009. Human Reprod 2009;24:2683-7.

18. Jaschevatzky OE, Shalit A, Grunstein S, Kaplanski J, Danon A. Increased decidual prostaglandin $\mathrm{E}$ concentration in human abortion. Br J Obstet Gynaecol 1983;90:958-60.

19. Abel MH, Smith SK, Baird DT. Suppression of concentration of endometrial prostaglandin in early intra-uterine and ectopic pregnancy in women. J Endocrinol 1980;85:379-86.

20. Kansal Kalra S, Ratcliffe SJ, Milman L, Gracia CR, Coutifaris C, Barnhart KT. Perinatal morbidity after in vitro fertilization is lower with frozen embryo transfer. Fertil Steril 2011;95:548-53.

21. Papanikolaou EG, Tournaye H, Verpoest W, Camus M, Vernaeve V, Van Steirteghem A, et al. Early and late ovarian hyperstimulation syndrome: early pregnancy outcome and profile. Human Reprod 2005;20:636-41.

22. Haadsma ML, Groen H, Mooij TM, Burger CW, Broekmans FJ, Lambalk CB, et al. Miscarriage risk for IVF pregnancies in poor responders to ovarian hyperstimulation. Reprod Biomed Online 2010;20:191-200.

23. Amor DJ, Xu JX, Halliday JL, Francis I, Healy DL, Breheny S, et al. Pregnancies conceived using assisted reproductive technologies (ART) have low levels of pregnancy-associated plasma protein-A (PAPP-A) leading to a high rate of false-positive results in first trimester screening for Down syndrome. Hum Reprod 2009;24:1330-8. 
24. Haouzi D, Assou S, Mahmoud K, Tondeur S, Rème T, Hedon B, et al. Gene expression profile of human endometrial receptivity: comparison between natural and stimulated cycles for the same patients. Hum Reprod 2009;24:1436-45.

25. Simon C, Cano F, Valbuena D, Remohi J, Pellicer A. Clinical evidence for a detrimental effect on uterine receptivity of high serum oestradiol concentrations in high and normal responder patients. Hum Reprod 1995; 10:2432-7.

26. Simón C, Garcia Velasco JJ, Valbuena D, Peinado JA, Moreno C, Remohí J, et al. Increasing uterine receptivity by decreasing estradiol levels during the preimplantation period in high responders with the use of a follicle-stimulating hormone step-down regimen. Fertil Steril 1998;70:234-9.

27. Valbuena D, Martin J, de Pablo JL, Remohí J, Pellicer A, Simón C. Increasing levels of estradiol are deleterious to embryonic implantation because they directly affect the embryo. Fertil Steril 2001;76:962-8.

28. Roque M, Lattes K, Serra S, Solà I, Geber S, Carreras R, et al. Fresh embryo transfer versus frozen embryo transfer in in vitro fertilization cycles: a systematic review and meta-analysis. Fertil Steril 2013;99:156-62

29. Lee VC, Chan CC, Ng EH, Yeung WS, Ho PC. Sequential use of letrozole and gonadotrophin in women with poor ovarian reserve: a randomized controlled trial. Reprod Biomed Online 2011;23:380-8.

30. Mitwally MF, Casper RF. Aromatase inhibition improves ovarian response to follicle-stimulating hormone in poor responders. Fertil Steril 2002;77:776-80.

31. Goswami SK, Das T, Chattopadhyay R, Sawhney V, Kumar J, Chaudhury $\mathrm{K}$, et al. A randomized single-blind controlled trial of letrozole as a low-cost IVF protocol in women with poor ovarian response: a preliminary report. Human Reprodn 2004;19:2031-5.
32. Davar R, Oskouian H, Ahmadi S, Firouzabadi RD. GnRH antagonist/ letrozole versus microdose GnRH agonist flare protocol in poor responders undergoing in vitro fertilization. Taiwan J Obstet Gynecol 2010;49:297-301.

33. Yarali H, Esinler I, Polat M, Bozdag G, Tiras B. Antagonist/letrozole protocol in poor ovarian responders for intracytoplasmic sperm injection: a comparative study with the microdose flare-up protocol. Fertil Steril 2009;92:231-5.

34. Schoolcraft WB, Surrey ES, Minjarez DA, Stevens JM, Gardner DK. Management of poor responders: can outcomes be improved with a novel gonadotropin-releasing hormone antagonist/letrozole protocol? Fertil Steril 2008;89:151-6.

35. Bosch E, Labarta E, Crespo J, Simón C, Remohí J, Jenkins J, et al. Circulating progesterone levels and ongoing pregnancy rates in controlled ovarian stimulation cycles for in vitro fertilization: analysis of over 4000 cycles. Hum Reprod 2010;25:2092-100.

36. Bahceci M, Ulug U, Ciray HN, Akman MA, Erden HF. Efficiency of changing the embryo transfer time from day 3 to day 2 among women with poor ovarian response: a prospective randomized trial. Fertil Steril 2006;86:81-5.

37. Dayal MB, Frankfurter D, Athanasiadis I, Peak D, Dubey A, Gindoff PR. Day 2 embryo transfer (ET) and day 3 ET afford similar reproductive outcomes in the poor responder. Fertil Steril 2011;95:1130-2.

38. Xin ZM, Zhang QL, Sun YP, Jin HX, Song WY. (Pregnancy outcomes of day-2 versus day-3 embryo transfer in poor responders). Zhonghua Nan Ke Xue 2012;18:522-6.

39. Schoolcraft WB, Katz-Jaffe MG. Comprehensive chromosome screening of trophectoderm with vitrification facilitates elective single-embryo transfer for infertile women with advanced maternal age. Fertil Steril 2013;100:615-9. 